\title{
PENGARUH STRES KERJA DAN KONFLIK KERJA TERHADAP KINERJA KARYAWAN PADA CV. DUTA KARYA (JASA PARKIR)
}

\author{
Akila *)
}

\section{ABSTRAK}

Tujuan dalam penelitian ini adalah untuk mengetahui dan menguji ada tidaknya pengaruh stres kerja dan konflik kerja terhadap kinerja karyawan pada CV.Duta Karya (Jasa Parkir). Teknik Pengumpulan data yang dilakukan dalam penelitian ini melalui penyebaran kuesioner kepada 31 orang karyawan CV.Duta Karya (Jasa Parkir). Adapun analisis data dalam penelitian ini adalah dengan menggunakan bantuan program SPSS (Statistical Product and Service Solution) Versi 22. Teknik pengujian data dalam penelitian ini meliputi uji validitas dan uji reliabilitas. Uji asumsi klasik yaitu uji normalitas, multikolonieritas, dan heteroskedastisitas. Uji koefisien korelasi dan koefisien determinasi untuk menguji dan membuktikan hipotesis penelitian serta pengujian hipotesis dengan mengunakan uji t dan uji $F$.

Hasil penelitian menunjukkan bahwa 1) variabel stres kerja secara parsial berpengaruh terhadap variabel kinerja karyawan, 2) variabel konflik kerja secara parsial berpengaruh terhadap variabel kinerja karyawan, 3) variabel stres kerja dan konflik kerja secara simultan terdapat pengaruh terhadap variabel kinerja karyawan.

Kata Kunci : Sters Kerja, Konflik Kerja, dan Kinerja Karyawan.

\section{PENDAHULUAN}

\subsection{Latar Belakang}

Secara umum dalam suatu organisasi atau perusahaan selalu menginginkan setiap karyawannya agar berprestasi. Dalam mencapai tujuan ini, suatu organisasi dalam bekerja dipengaruhi banyak faktor salah satunya yang dapat mempengaruhi kinerja adalah apabila karyawan mampu menghadapi kesulitan baik di dalam maupun di luar pekerjaan. Stres merupakan salah satu masalah yang pasti akan dihadapi oleh setiap orang dalam kehidupannya dan stres tersebut harus diatasi dengan baik oleh karyawan tanpa bantuan orang lain maupun dengan bantuan pihak lain. Secara sederhana stres merupakan tanggapan seseorang baik secara fisik maupun mental terhadap suatu perubahan di lingkungannya yang dirasakan mengganggu dan mengakibatkan dirinya terancam. Jadi sebenarnya stres merupakan sesuatu yang sangat ilmiah. Kondisi pekerjaan yang tidak dimungkinkan bisa menyebabkan stres tergantung seberapa besar kemampuan karyawan dalam menerimanya.

Masalah-masalah tentang stres kerja pada dasarnya sering dikaitkan dengan pengertian stres yang sering terjadi di lingkungan pekerjaan, yaitu dalam proses interaksi antara seorang karyawan dengan aspek-aspek pekerjaannya (Riva'i dan Mulyadi, 2010:307). Secara singkat, dapat dikatakan bahwa stres kerja dapat timbul jika tuntutan pekerjaan tidak seimbang dengan kemampuan untuk memenuhi tuntutannya tersebut sehingga dapat menimbulkan stres kerja dengan berbagai taraf (Suwatno dan Priansa, 2013:255).

Faktor lain yang dapat mempengaruhi kinerja karyawan adanya indikasi konflik kerja. Orang-orang dalam kelompok organisasi mengembangkan keahlian dan pandangan yang 
berbeda

tentang

pekerjaan/tugasnya dengan

pekerjaan / tugas kelompok lain.

Ketika interaksi di antara mereka terjadi maka konflik menjadi potensial untuk muncul. Dalam kehidupan berorganisasi, setiap saat dapat terjadi konflik baik berbentuk konflik antar individu sebagai anggota organisasi, terjadi di dalam diri individu masing-masing, maupun konflik antara anggota atau organisasi dengan orang luar/masyarakat. Kondisi konflik tidak menguntungkan bagi kepemimpinan karena akan menimbulkan berbagai kesulitan dalam menggerakkan anggota agar bekerja sama, dalam usaha mencapai tujuan organisasi (Rivai'i dan Mulyadi, 2010:273).

$$
\text { Konflik dilatarbelakangi }
$$

oleh perbedaan karakteristik pada individu dalam suatu interaksi. Perbedaan-perbedaan tersebut menyangkut pengetahuan, skill, adat istiadat, keyakinan, dan lain sebagainya. Pada dasarnya konflik bukanlah sesuatu hal yang buruk, konflik dapat memberikan dampak yang positif. Konflik dapat membuat seseorang lebih termotivasi untuk berprestasi dan bersaing secara sehat. Walaupun konflik bukan merupakan sesuatu hal yang buruk, konflik dapat menimbulkan dampak negatif yang sifatnya merugikan bukan hanya bagi individu atau kelompok yang mengahadapinya tetapi juga perusahaan secara keseluruhan.

Agar konflik tidak menimbulkan pengaruh yang sifatnya negatif, konflik harus tetap dijaga agar tetap berada pada batas-batas yang wajar. Pemahaman tentang konflik harus dapat dipahami dengan baik oleh pihak-pihak yang bersangkutan agar tidak menimbulkan masalah yang berkepanjangan. Dalam hal ini peran manajemen sangat penting untuk melakukan pendekatan secara efektif, seperti membuat kebijakan yang lebih dapat diterima oleh semua pihak dan bersikap lebih terbuka dalam menanggapi pendapat para karyawan.

Permasalahan mengenai stres kerja dan konflik kerja yang telah dijelaskan di atas merupakan sesuatu yang pasti dihadapi oleh setiap perusahaan tidak terkecuali CV.Duta Karya (Jasa Parkir), rendahnya kinerja karyawan menyebabkan tujuan perusahaan tidak tercapai dengan baik karena terdapat tindakan yang tidak mendukung efektivitas dan efisiensi dalam melakukan pekerjaan. Akibatnya perusahaan harus menerima kerugian materil maupun immaterial karena pekerjaan karyawan yang selalu tidak tepat waktu.

Berdasarkan uraian dan fakta yang diperoleh dari CV.Duta Karya (Jasa Parkir) maka peneliti tertarik untuk melakukan penelitian mengenai : "Pengaruh Stres Kerja dan Konflik Kerja terhadap Kinerja Karyawan pada CV.Duta Karya (Jasa Parkir)."

\subsection{Rumusan Masalah}

Berdasarkan latar belakang di atas maka rumusan masalah dalam penelitian ini adalah sebagai berikut :

1. Apakah ada pengaruh stres kerja terhadap kinerja karyawan pada CV.Duta Karya (Jasa Parkir) ? 
2. Apakah ada pengaruh konflik kerja terhadap kinerja karyawan pada CV.Duta Karya (Jasa Parkir) ?

3. Apakah ada pengaruh stres kerja dan konflik kerja secara bersama-sama terhadap kinerja karyawan CV.Duta Karya (Jasa Parkir)?

\section{TINJAUAN TEORI}

\subsection{Stres kerja}

Menurut Gibson dalam

Riva'i dan Mulyadi (2010:307) mengemukakan bahwa stres kerja dikonseptualisasi dari beberapa titik pandang, yaitu stres sebagai stimulus, stres sebagai respons, dan stres sebagai stimulus-respons. Stres sebagai stimulus, merupakan pendekatan yang menitikberatkan pada lingkungan. Pendekatan ini memamndang stres sebagai konsekuensi antara stimulus lingkungan dengan respons individu.

Sedangkan menurut Luthans dalam Riva'i dan Mulyadi (2010:307-308) mendefinisikan stres sebagai suatu tanggapan dalam menyesuaikan diri yang dipengaruhi oleh perbedaan individu dan proses psikologis, sebagai konsekuensi dari tindakan lingkungan, situasi atau peristiwa yang terlalu banyak mengadakan tuntutan psikologis dan fisik seseorang.

$$
\text { Namun Baron dan }
$$

Greenberg dalam Riva'i dan Mulyadi

(2010:308) mendefinisikan stres kerja sebagai reaksi-reaksi emosional dan psikologis yang terjadi pada situasi dimana tujuan individu mendapat halangan dan tidak bisa mengatasinya.
Kemudian Aamodt dalam Riva'i dan Mulyadi (2010:308) memandang stres kerja sebagai respons adaptif yang merupakan karakteristik individual dan konsekuensi dan tindakan eksternal, situasi atau peristiwa yang terjadi baik secara fisik maupun psikologis.

Dan Landi dalam Riva'i dan Mulyadi (2010:308) memahami bahwa stres adalah sebagai ketidakseimbangan keinginan dan kemampuan memenuhinya sehingga menimbulkan konsekuensi penting bagi dirinya.

Dan menurut Robbins dalam Riva'i dan Mulyadi (2010:308) memberikan definisi stres sebagai suatu kondisi dinamis dimana individu diharapkan pada kesempatan, hambatan dan keinginan dan hasil yang diperoleh sangatlah penting, tetapi tidak dapat dipastikan.

Menurut Soewondo dalam Suwatno dan Priansa (2013:225) menyatakan bahwa stres kerja adalah suatu kondisi dimana terdapat satu atau beberapa faktor di tempat kerja yang berinteraksi dengan pekerja sehingga mengganggu kondisi fisiologis, dan perilaku. Stres kerja akan muncul bila terdapat kesenjangan antara kemampuan individu dengan tuntutan-tuntutan dari pekerjaannya.

Dari uraian diatas maka pengertian stres kerja adalah sebuah keadaan dimana terjadi perubahan pada seorang karyawan yang menyimpang dari hal-hal normal mereka sebelumnya sebagai akibat dari adanya suatu masalah yang sedang dihadapi oleh karyawan 
tersebut maupun adanya ketidaksesuaian dengan pekerjaan yang dijalani oleh karena adanya berbagai tuntutan yang terjadi.

\subsection{Konflik Kerja}

Menurut Nawawi dan Hadari (2012:196) konflik kerja merupakan suasana batin yang berisi kegelisahan karena pertentangan dua motif atau lebih, yang mendorong seseorang berbuat dua atau lebih kegiatan yang saling bertentangan, pada waktu yang bersamaan.

Sedangkan menurut Fahmi (2013:205) konflik adalah sebuah persepsi yang berbeda dalam melihat suatu siatuasi dan kondisi yang selanjutnya teraplikasi dalam bentuk aksi-aksi sehingga telah menimbulkan pertentangan dengan pihak-pihak tertentu.

Bedasarkan pengertian para ahli dapat disimpulkan bahwa konflik kerja adalah ketidaksesuaian antara dua orang atau lebih di dalam perusahaan karena adanya perbedaan pendapat, nilai-nilai, tujuan, serta kompetisi untuk memperebutkan posisi dan kekuasaan menurut sudut pandang masing-masing untuk mencapai tujuan organisasi.

\subsection{Kinerja Karyawan}

Kinerja pada dasarnya merupakan perilaku nyata yang dihasilkan setiap orang sebagai prestasi kerja yang dihasilkan oleh karyawan sesuai dengan perannya dalam perusahaan. Untuk mendapatkan kinerja yang baik dari seorang karyawan pada sebuah organisasi harus dapat memberikan sarana dan prasarana sebagai penunjang dalam menyelesaikan pekerjaan. Istilah kinerja sendiri merupakan tujuan dari kata job performance atau aktual performance (prestasi kerja atau prestasi sesungguhnya yang dicapai oleh seseorang).

Amstron dan Baron dalam Fahmi (2013:227) mengemukakan bahwa kinerja merupakan hasil pekerjaan yang mempunyai hubungan kuat dengan tujuan strategis organisasi, kepuasan konsumen dan memberikan kontribusi ekonomi.

Sedangkan menurut Indra Bastian dalam Fahmi (2013:227) menyatakan bahwa kinerja adalah gambaran mengenai tingkat pencapaian pelaksanaan suatu kegiatan/program/kebijaksanaan dalam mewujudkan sasaran, tujuan, misi dan visi organisasi yang tertuang dalam perumusan skema strategis (strategic planning) suatu organisasi.

Sedangkan

menurut Nasucha dalam Fahmi (2013:228) kinerja adalah sebagai efektifitas organisasi secara menyeluruh untuk memenuhi kebutuhan yang ditetapkan dari setiap kelompok yang berkenaan dengan usahausaha yang sistematik dan meningkatkan kemampuan organisasi secara terus menerus untuk mencapai kebutuhannya secara efektif.

Dari beberapa pengertian di atas maka dapat disimpulkan bahwa pengertian kinerja adalah prestasi atau hasil kerja baik kualitas maupun kuantitas yang dicapai Sumber Daya Manusia dalam melaksanakan tugasnya 
sesuai dengan tanggung jawab yang diberikan kepadanya.

\subsection{Penelitian Terdahulu yang Relevan}

1. Denny Nur Diansyah (2010) penelitian dengan judul Pengaruh Stres Kerja dan Konflik Kerja terhadap Kinerja Karyawan Dinas Pekerjaan Umum Pemerintah Kota Surakarta. Hasil penelitian menunjukkan bahwa secara parsial terdapat pengaruh yang signifikan stres kerja dan konflik kerja terhadap kinerja karyawan dan stres kerja dan konflik kerja secara bersama-sama berpengaruh signifikan terhadap kinerja karyawan.

2. Ria Puspita Sari (2015) penelitian dengan judul Pengaruh Stres Kerja dan Konflik Kerja terhadap Kinerja
Karyawan Jambuluwuk Malioboro Boutique Hotel Yogyakarta. Hasil penelitian menunjukkan bahwa secara parsial stres kerja dan konflik kerja berpengaruh terhadap kinerja karyawan dan stres kerja dan konflik kerja secara bersama-sama berpengaruh terhadap kinerja karyawan.

\subsection{Kerangka Pemikiran}

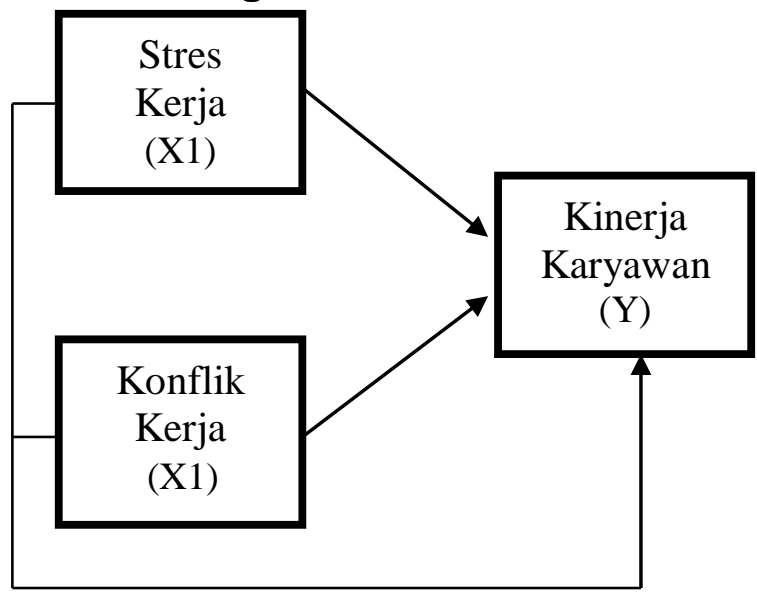

Gambar 1. Kerangka pemikiran

\section{PROSEDUR PENELITIAN}

\subsection{Definisi Operasional Variabel}

Tabel 1. Definisi Operasional Variabel

\begin{tabular}{|c|c|c|}
\hline Varibel & Definisi Variabel & Indikator \\
\hline $\begin{array}{l}\text { Stres Kerja } \\
\left(\mathrm{X}_{1}\right)\end{array}$ & $\begin{array}{l}\text { Stres kerja suatu tanggapan dalam } \\
\text { menyesuaikan diri yang dipengaruhi oleh } \\
\text { perbedaan individu dan proses psikologis, } \\
\text { sebagai konsekuensi dari tindakan lingkungan, } \\
\text { situasi atau peristiwa yang terlalu banyak } \\
\text { mengadakan tuntutan psikologis dan fisik } \\
\text { seseorang. } \\
\text { Luthans dalam Riva'i dan Mulyadi (2010:307-308) }\end{array}$ & $\begin{array}{l}\text { 1. Gejala Psikologis } \\
\text { 2. Gejala Fisiologis } \\
\text { 3. Gejala Perilaku } \\
\text { Terry Beehr dan John Newman } \\
\text { dalam Riva'i dan Mulyadi } \\
\text { (2010:317-318) }\end{array}$ \\
\hline $\begin{array}{l}\text { Konflik } \\
\text { Kerja }\left(X_{2}\right)\end{array}$ & $\begin{array}{l}\text { Konflik adalah sebuah persepsi yang berbeda } \\
\text { dalam melihat suatu siatuasi dan kondisi yang } \\
\text { selanjutnya teraplikasi dalam bentuk aksi-aksi } \\
\text { sehingga telah menimbulkan pertentangan } \\
\text { dengan pihak-pihak tertentu. Fahmi (2013:205) }\end{array}$ & $\begin{array}{l}\text { 1. Koordinasi dan Kontrol } \\
\text { 2. Keterbatasan Sumber Daya } \\
\text { 3. Kewenangan dan } \\
\text { Pembuatan Keputusan } \\
\text { 4. Komunikasi } \\
\text { 5. Salah Pengertian } \\
\text { 6. Emosi } \\
\text { 7. Sudut Pandang } \\
\text { 8. Nilai-Nilai } \\
\text { Armala (2015:111-113) }\end{array}$ \\
\hline
\end{tabular}




\begin{tabular}{|l|l|l|}
\hline Kinerja & Kinerja adalah sebagai efektifitas organisasi & 1. Tujuan \\
Karyawan & secara menyeluruh untuk memenuhi kebutuhan & 2. Standar \\
(Y) & yang ditetapkan dari setiap kelompok yang & 3. Umpan balik \\
& berkenaan dengan usaha-usaha yang sistematik & 4. Alat atau sarana \\
& dan meningkatkan kemampuan organisasi secara & 5. Kompetensi \\
& terus menerus untuk mencapai kebutuhannya & 6. Motif \\
& secara efektif. & 7. Peluang \\
& Nasucha dalam Fahmi (2013:228) & Hersey, Blanchard, dan Johnson \\
& dalam Wibowo (2012:102) \\
\hline
\end{tabular}

\subsection{Populasi dan Sampel}

Menurut Sujarweni (2015:80) populasi merupakan keseluruhan jumlah yang terdiri atas objek atau subjek yang mempunyai karakteristik dan kualitas tertentu yang ditetapkan oleh peneliti untuk diteliti dan kemudian ditarik kesimpulannya. Populasi dalam penelitian ini adalah seluruh karyawan yang ada di CV. Duta Karya (Jasa Parkir) 122 orang karyawan.

Sampel menurut Sugiyono (2015:81), adalah bagian dari jumlah dan karakteristik yang memiliki oleh populasi tersebut.Sselanjutnya Arikunto (2002:112), apabila subjek yang diteliti kurang dari 100, lebih baik di ambil semua hingga penelitiannya merupakan penelitian populasi, sedangkan jika jumlah subjeknya lebih dari 100. Maka di ambil 10\%-15\% atau 20\%-25\% tergantung dari kemampuan peneliti yang dilihat dari segi waktu dan lulusnya wilayah penelitian. Berdasarkan pendapat tersebut diatas, penulis mengambil $25 \%$ dari populasi yang ada sebagai sampel penelitian. Yaitu: $25 \% \times 121=$ 30,25 atau di bulatkan menjadi 30 karyawan.

\subsection{Rancangan Penelitian}

Penelitian ini termasuk dalam kategori metode penelitian kuantitatif dengan menggunakan jenis pendekatan studi korelasional, karena gejala yang diamati melibatkan hubungan satu atau lebih variabel. Menurut Purwanto (2008) studi korelasional pada dasarnya merupakan hubungan antar variable dalam satu kelompok yang dapat berbentuk bivariat, multivariat, dan kanonik. Hanya saja dalam kajian ini, hubungan yang terjadi berbentuk bivariat dan multivariat, yaitu hubungan antara dua variabel bebas (stres kerja adalah $\mathrm{X}_{1}$ ) dan konflik kerjaq adalah $X_{2}$ ) baik secara sendiri-sendiri maupun bersamasama terhadap variabel terikat (kinerja karyawan adalah Y).

\subsection{Skala Pengukuran}

Menurut Siregar (2013), adapun teknik pengukuran variabel yang digunakan oleh peneliti untuk memberikan jawaban adalah dengan menggunakan skala likert. Skala likert adalah skala yang dapat digunakan untuk mengukur sikap, pendapat, dan persepsi seseorang tentang suatu objek atau penomenal tertentu. Nilai jawaban yang diberikan responden atau masing-masing item dihitung menggunakan score. Adapun score yang digunakan adalah skala likert yaitu pertayaan yang menunjukan tingkat kesetujuan atau ketidaksetujuan responden. Skala ini digunakan untuk respon subyek (koresponden) tentang 
fenomena sosial, dimana respon ini diukur ke dalam 5 poin skala dengan interval yang sama, yaitu nilai yang tertinggi 5 dan nilai yang terendah adalah 1. Skala ini terdiri 5 penilaian, yaitu sangat setuju (score 5), setuju (score 4), netral (score 3), tidak setuju (score 2), dan sangat tidak setuju (score 1).

\subsection{Teknik Pengumpulan Data}

Teknik pengumpulan data
dalam penulisan ini
menggunakan teknik yaitu:

1) Kuesioner

Menurut Sugiyono (2012:199)

kuesioner merupakan teknik pengumpulan data yang dilakukan dengan cara memberi seperangkat pertanyaan atau pernyataan tertulis kepada responden untuk dijawabnya. Kuesioner merupakan teknik pengumpulan data yang efisien bila peneliti tahu dengan pasti variabel yang akan diukur dan tahu apa yang bisa diharapkan dari responden.

2) Studi Dokumen

Menurut Sujarweni (2015:32) studi dokumen merupakan metode pengumpulan data kualitatif sejumlah besar fakta dan data tersimpan dalam bahan yang berbentuk dokumentasi. Sebagian besar data berbentuk surat, catatan harian, arsip foto, hasil rapat, cinderamata, jurnal kegiatan dan sebagainya.

\subsection{Uji Coba Instrumen}

1. Uji Validitas

(2014:51)

Menurut

Priyatno menjelaskan bahwa uji validitas digunakan untuk mengukur valid atau tidaknya suatu variabel, uji validitas dilakukan dengan melakukan korelasi bivariate antara masing-masing skor indikator dengan total variabel. Uji korelasi yang digunakan adalah Korelasi Product Moment. Nilai $r$ product moment ini dibandingkan dengan nilai $r$ product moment. Jika nilai $r_{\text {hitung }} \geq r_{\text {tabel }}$ berarti kuesioner tersebut valid

\section{Uji Reliabilitas}

Menurut Priyatno (2014:64) menjelaskan bahwa uji reliabilitas digunakan untuk mengetahui konsistensi alat ukur yang biasanya menggunakan kuesioner. Untuk mencari pengujian reliabilitas peneliti menggunakan alat ukur skala rentangan (seperti skala likert 1-5) yaitu croanbach's alpha. Suatu suatu instrument dikatakan reliabel jika nilai cornbach's alpha $(\alpha)$ lebih besar dari 0,6.

\subsection{Uji Asumsi Klasik}

Penulis dalam penelitian ini menggunakan uji asumsi klasik yang meliputi uji normalitas, uji multikolonieritas, dan uji heteroskedastisitas, dengan menggunakan bantuan program SPSS Versi 22.

1. Uji Normalitas

Menurut

Ghozali

(dalam Sujarweni 2015:225) uji normalitas bertujuan untuk menguji apakah dalam model regresi, variabel terikat dan variabel bebas keduanya mempunyai distribusi normal ataukah tidak. Uji normalitas 
data dapat dilakukan dengan menggunakan uji Kolmogorov Smirnov satu arah. Pengambilan kesimpulan untuk menentukan apakah suatu data mengikuti distribusi normal atau tidak adalah jika signifikan > 0,05 maka variabel berdistribusi normal dan jika signifikan < 0,05 maka variabel tidak berditribusi normal.

2. Uji Multikolinearitas

Menurut Ghozali (dalam Sujarweni 2015:226227) uji multikolinearitas berarti ada hubungan linier yang sempurna atau pasti diantara beberapa atau semua variabel yang independen dari model yang ada. Uji multikolinearitas bertujuan untuk menguji apakah pada model regresi ditemukan kolerasi antar variabel bebas. Pada model regresi yang baik seharusnya tidak terjadi kolerasi diantara variabel bebas. Metode untuk menguji adanya multikolinearitas ini dapat dilihat dari Tolerance Value Variance Inflantion Factor (VIF). Jika VIF > 10 atau jika tolerance value $<0,1$ maka terjadi multikolinearitas dan Jika VIF < 10 atau jika tolerance value > 0,1 maka tidak terjadi multikolinearitas.

3. Uji Heteroskedastisitas Menurut Ghozali (dalam Sujarweni 2015:226227) uji heteroskedastisitas adalah suatu keadaan dimana varians dan kesalahan pengganggu tidak konstan untuk semua variabel bebas. Model regresi yang baik adalah tidak terjadi heteroskedastisitas. Cara memprediksi ada tidaknya heteroskedastisitas pada suatu model dapat diuji dengan menggunakan teknik koefisien korelasi spearman's rho, yaitu mengorelasikan variabel independen dengan residualnya. Pengujian menggunakan tingkan signifikansi 0,05 dengan uji 2 sisi. Jika korelasi antar variabel independen dengan residual didapat sig. > 0,05 maka dapat dikatakan bahwa tidak terjadi masalah heteroskedastisitas.

\subsection{Teknik Analisis Data}

Menurut

Sujarweni (2015:121) analisis data diartikan sebagai upaya data yang sudah tersedia kemudian diolah dengan statistik dan dapat digunakan untuk menjawab rumusan masalah dalam penelitian.

\section{Analisis Regresi Linier} Berganda

$\begin{array}{rr}\text { Priyatno } & (2014: 148) \\ \text { mengemukakan } & \text { bahwa }\end{array}$
analisis regresi ini bertujuan untuk mengetahui pengaruh atau hubungan secara linier antara Stres Kerja $\left(\mathrm{X}_{1}\right)$ dan Konflik Kerja $\left(X_{2}\right)$ dengan Kinerja Karyawan $(Y)$ dimana ketiga variabel tersebut Stres Kerja dan Konflik Kerja sebagai variabel bebas, dan Kinerja Karyawan sebagai variabel terikat.

\section{Koefisien Determinasi $\left(\mathbf{R}^{2}\right)$ \\ Koefisien determinasi} $\left(R^{2}\right)$ pada intinya mengukur seberapa jauh kemampuan model (stres kerja, konflik kerja) dalam menerangkan 
variasi variabel dependent atau tidak bebas (kinerja karyawan). Nilai koefisien determinasi adalah antara nol (0) dan (1). Nilai $R^{2}$ yang kecil berarti kemampuankemampuan variabel independent (bebas) dalam menjelaskan variasi variabel dependent sangat terbatas.

Nilai yang mendekati satu (1) berarti variabelvariabel independent memberikan hampir semua informasi yang dibutuhkan untuk memprediksi variasi variabel dependent. Secara umum koefisien determinasi untuk data silang (crossection) relatif rendah karena adanya variasi yang besar antara masing-masing pengamatan, sedangkan untuk data runtun waktu (time series) biasanya mempunyai nilai koefisien determinasi yang tinggi (Ghozali, 2005:83).

\subsection{Pengujian Hipotesis}

1. Uji t (Secara Parsial)

Priyatno

(2014:144) digunakan untuk mengetahui apakah masing-masing variabel bebasnya secara sendiri-sendiri berpengaruh secara signifikan terhadap variabel terikat dimana jika sig > ó $(0,05)$, maka $\mathrm{H}_{0}$ diterima dan $\mathrm{H}_{1}$ ditolak dan sebaliknya jika sig < ó $(0,05)$ maka $\mathrm{H}_{0}$ ditolak dan $\mathrm{H}_{1}$ diterima.

2. Uji $F$ (Secara Simultan)

Priyatno menjelaskan bahwa uji $F$ berfungsi untuk mengetahui signifikasi pengaruh / hubungan antara semua variabel bebas dan variabel terikat. Penerimaan atau penolakan $\mathrm{H}_{0}$ dapat dilihat dari nilai probabilitas (sig F) dimana jika sig < a maka $\mathrm{H}_{0}$ ditolak dan $\mathrm{H}_{a}$ diterima dan jika sig > a maka $\mathrm{H}_{0}$ diterima dan $\mathrm{H}_{\mathrm{a}}$ ditolak.

\section{HASIL PENELITIAN DAN PEMBAHASAN}

\subsection{HASIL PENELITIAN}

1. Hasil Uji Coba Instrumen

a. Hasil Uji Validitas

1) Uji Validitas Stres Kerja $\left(X_{1}\right)$

Tabel 2. Rekap Uji Validitas Stres Kerja $\left(X_{1}\right)$

\begin{tabular}{|c|l|c|c|c|}
\hline No & Item & $\mathbf{r}_{\text {tabel }}$ & rhitung $_{\text {Keterangan }}$ & Valid \\
\hline $\mathbf{1}$ & Item 1 & 0,197 & 0,480 & Valid \\
\hline $\mathbf{2}$ & Item 2 & 0,197 & 0,544 & Valid \\
\hline $\mathbf{3}$ & Item 3 & 0,197 & 0,535 & Valid \\
\hline $\mathbf{4}$ & Item 4 & 0,197 & 0,553 & Valid \\
\hline $\mathbf{5}$ & Item 5 & 0,197 & 0,408 & Valid \\
\hline $\mathbf{6}$ & Item 6 & 0,197 & 0,570 & Valid \\
\hline $\mathbf{7}$ & Item 7 & 0,197 & 0,460 & Valid \\
\hline $\mathbf{8}$ & Item 8 & 0,197 & 0,658 & Valid \\
\hline $\mathbf{9}$ & Item 9 & 0,197 & 0,402 & Valid \\
\hline $\mathbf{1 0}$ & Item 10 & 0,197 & 0,575 & \\
\hline
\end{tabular}

Sumber : Data Primer yang Diolah SPSS Versi 22 
Dari hasil pengolahan data menggunakan program SPSS 22 For Windows menunjukkan bahwa hasil uji validitas dari 10 item pernyataan pada variabel Stres Kerja $\left(X_{1}\right)$ keseluruhannya valid. Dengan demikian keseluruhan item pertanyaan yang ada pada instrumen tersebut dapat dijadikan sebagai alat ukur yang valid dalam analisis selanjutnya.

2) Uji Validitas Konflik Kerja $\left(\mathrm{X}_{2}\right)$

Tabel 3. Rekap Hasil Uji Validitas Konflik Kerja $\left(\mathbf{X}_{2}\right)$

\begin{tabular}{|c|l|c|c|c|}
\hline No. & Item & $\mathbf{r}_{\text {tabel }}$ & $\mathbf{r}_{\text {hitung }}$ & Keterangan \\
\hline 1 & Item 1 & 0,197 & 0,586 & Valid \\
\hline 2 & Item 2 & 0,197 & 0,445 & Valid \\
\hline 3 & Item 3 & 0,197 & 0,654 & Valid \\
\hline 4 & Item 4 & 0,197 & 0,700 & Valid \\
\hline 5 & Item 5 & 0,197 & 0,689 & Valid \\
\hline 6 & Item 6 & 0,197 & 0,649 & Valid \\
\hline 7 & Item 7 & 0,197 & 0,606 & Valid \\
\hline 8 & Item 8 & 0,197 & 0,746 & Valid \\
\hline 9 & Item 9 & 0,197 & 0,510 & Valid \\
\hline 10 & Item 10 & 0,197 & 0,633 & Valid \\
\hline
\end{tabular}

Sumber : Data Primer yang Diolah SPSS Versi 22

Dari hasil pengolahan data menggunakan program SPSS 22 For Windows menunjukkan bahwa hasil uji validitas dari 10 item pertanyaan pada variabel Konflik Kerja $\left(\mathrm{X}_{2}\right)$ keseluruhannya valid. Dengan demikian keseluruhan item pertanyaan yang ada pada instrumen tersebut dapat dijadikan sebagai alat ukur yang valid dalam analisis selanjutnya.

3) Uji Validitas Kinerja Karyawan ( $Y$ )

Tabel 4. Rekap Hasil Uji Validitas Kinerja Karyawan ( $Y$ )

\begin{tabular}{|c|l|c|c|c|}
\hline No. & \multicolumn{1}{|c|}{ Item } & $\mathbf{r}_{\text {tabel }}$ & $\mathbf{r}_{\text {hitung }}$ & Keterangan \\
\hline 1 & Item 1 & 0,197 & 0,282 & Valid \\
\hline 2 & Item 2 & 0,197 & 0,305 & Valid \\
\hline 3 & Item 3 & 0,197 & 0,630 & Valid \\
\hline 4 & Item 4 & 0,197 & 0,630 & Valid \\
\hline 5 & Item 5 & 0,197 & 0,681 & Valid \\
\hline 6 & Item 6 & 0,197 & 0,599 & Valid \\
\hline 7 & Item 7 & 0,197 & 0,625 & Valid \\
\hline 8 & Item 8 & 0,197 & 0,688 & Valid \\
\hline 9 & Item 9 & 0,197 & 0,503 & Valid \\
\hline 10 & Item 10 & 0,197 & 0,502 & Valid \\
\hline
\end{tabular}

Sumber : Data Primer yang Diolah SPSS Versi 22

Dari hasil pengolahan data menggunakan program SPSS 22 For Windows menunjukkan bahwa hasil uji validitas dari 10 item pertanyaan pada variabel Kinerja Karyawan keseluruhannya valid. Dengan demikian keseluruhan item pertanyaan yang ada pada instrumen tersebut dapat dijadikan sebagai alat ukur yang valid dalam analisis selanjutnya. 


\section{b. Hasil Uji Reliabilitas}

Tabel 5. Hasil Pengujian Reliabilitas

\begin{tabular}{|l|c|c|}
\hline \multicolumn{1}{|c|}{ Variabel } & Nilai Cronbach Alpha & Keterangan \\
\hline Stres kerja & 0,847 & Reliabel \\
\hline Konflik kerja & 0,800 & Reliabel \\
\hline Kinerja karyawan & 0,881 & Reliabel \\
\hline
\end{tabular}

Sumber : Data Primer yang diolah 2015

Hasil uji reliabilitas tersebut menunjukkan bahwa semua variabel mempunyai koefisien Alpha diatas 0,6 sehingga dapat dikatakan semua konsep pengukur masing-masing variabel dari kuesioner adalah reliabel yang berarti bahwa kuesioner yang digunakan dalam penelitian ini merupakan kuesioner yang handal.

\section{Uji Asumsi Klasik}

\section{a. Uji Normalitas}

Uji ini untuk menguji apakah pengamatan berdistribusi normal atau tidak, uji ini menggunakan kolmogrov-Smirnov. Hasil uji normalitas dapat dilihat sebagai berikut :

Tabel 6. Hasil Uji Normalitas

One-Sample Kolmogorov-Smirnov Test

\begin{tabular}{|c|c|c|c|c|}
\hline & & Stres Kerja & Konflik Kerja & $\begin{array}{l}\text { Kinerja } \\
\text { Karyawan }\end{array}$ \\
\hline N & & 31 & 31 & 31 \\
\hline \multirow[t]{2}{*}{ Normal Parameters ${ }^{a, b}$} & Mean & 4.0387 & 3.9323 & 4.0065 \\
\hline & Std. Deviation & .43411 & .41019 & .43123 \\
\hline \multirow[t]{3}{*}{ Most Extreme Differences } & Absolute & .117 & .144 & .188 \\
\hline & Positive & .116 & .144 & .188 \\
\hline & Negative & -.117 & -.083 & -.177 \\
\hline Kolmogorov-Smirnov Z & & .649 & .802 & 1.049 \\
\hline Asymp. Sig. (2-tailed) & & .793 & .540 & .222 \\
\hline
\end{tabular}

a. Test distribution is Normal.

b. Calculated from data.

Sumber : Data Primer yang Diolah SPSS Versi 22

Berdasarkan hasil uji normalitas data menggunakan One Sample Kolmogorov Smirnov Test, sebagaimana tersaji pada tabel diatas dapat disimpulkan bahwa semua variabel memiliki data normal, hal tersebut dikarenakan semua variabel tersebut memiliki Asymp. Sig $>0,05$ b. Uji Multikolinearitas Tabel 7. Hasil Uji Multikolinearitas Coefficients $^{a}$

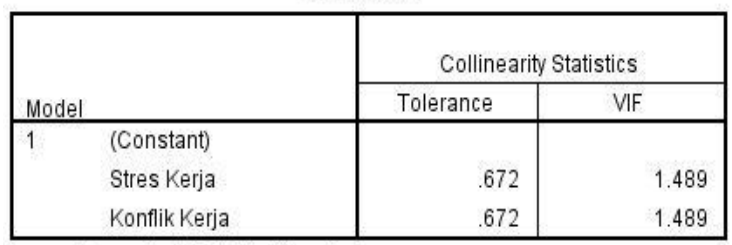

a. Dependent Variable: Kinerja Karyawan

Sumber : Data Primer yang Diolah SPSS Versi 22 
Berdasarkan tabel di atas diketahui bahwa semua variable mempunyai nilai tolerance $>0.10$ dan nilai VIF tidak ada yang melebihi dari 10, dengan

demikian maka dapat disimpulkan bahwa tidak terjadi multikolineritas antar variabel bebas dalam model regresi.

\section{c. Uji Heteroskedastisitas}

Tabel 8. Hasil Uji Heterskedastisitas

Correlations

\begin{tabular}{|c|c|c|c|c|c|}
\hline & & & $\begin{array}{l}\text { Stres } \\
\text { Kerja }\end{array}$ & $\begin{array}{c}\text { Konflik } \\
\text { Kerja }\end{array}$ & $\begin{array}{c}\text { Unstandardized } \\
\text { Residual }\end{array}$ \\
\hline \multirow{9}{*}{$\begin{array}{l}\text { Spearman's } \\
\text { rho }\end{array}$} & \multirow[t]{3}{*}{ Stres Kerja } & Correlation Coefficient & 1.000 & $.495^{11}$ & -.066 \\
\hline & & Sig. (2-tailed) & & .005 & .723 \\
\hline & & N & 31 & 31 & 31 \\
\hline & \multirow[t]{3}{*}{ Konflik Kerja } & Correlation Coefficient & $.495^{n}$ & 1.000 & -.106 \\
\hline & & Sig. (2-tailed) & .005 & . & .571 \\
\hline & & $\mathrm{N}$ & 31 & 31 & 31 \\
\hline & \multirow{3}{*}{$\begin{array}{l}\text { Unstandardized } \\
\text { Residual }\end{array}$} & Correlation Coefficient & -.066 & -.106 & 1.000 \\
\hline & & Sig. (2-tailed) & .723 & .571 & \\
\hline & & $\mathrm{N}$ & 31 & 31 & 31 \\
\hline
\end{tabular}

**. Correlation is significant at the 0.01 level (2-tailed).

Sumber : Data Primer yang Diolah SPSS Versi 22

Berdasarkan hasil uji heteroskedastisitas dengan menggunakan uji koefisien korelasi spearman's rho dapat dilihat bahwa korelasi antara variabel bebas dengan unstandardized residual memiliki nilai signifikan lebih dari 0,05 . Karena signifikansi lebih besar daripada 0,05, maka dapat disimpulkan bahwa tidak terjadi problem heteroskedasitas.

\section{Hasil Teknik Analisis Data}

\section{a. Analisis Regresi Linier Berganda}

Tabel 9. Hasil Regresi Linier Berganda

Coefficients $^{a}$

\begin{tabular}{|c|c|c|c|c|c|c|}
\hline \multirow[b]{2}{*}{ Mod } & & \multicolumn{2}{|c|}{ Unstandardized Coefficients } & \multirow{2}{*}{$\begin{array}{c}\begin{array}{c}\text { Standardized } \\
\text { Coefficients }\end{array} \\
\text { Beta }\end{array}$} & \multirow[b]{2}{*}{$t$} & \multirow[b]{2}{*}{ Sig. } \\
\hline & & $B$ & Std. Error & & & \\
\hline \multirow[t]{3}{*}{1} & (Constant) & .552 & .569 & & .969 & .341 \\
\hline & Stres Kerja & .495 & .150 & 499 & 3.310 & .003 \\
\hline & Konflik Kerja & .370 & .158 & .352 & 2.337 & .027 \\
\hline
\end{tabular}

a. Dependent Variable: Kinerja Karyawan

Sumber : Data Primer yang Diolah SPSS Versi 22

Berdasarkan tabel diatas diperoleh nilai koefisien regresi untuk stres kerja $\left(X_{1}\right)$ sebesar 0,495 dan nilai koefisien regresi untuk konflik kerja $\left(\mathrm{X}_{2}\right)$ sebesar 0,370. Dan koefisien konstanta sebesar 0,552. Berdasarkan nilai tersebut diperoleh persamaan regresi linier berganda adalah sebagai berikut :

$Y=0,552+0,495 X_{1}+0,370 X_{2}$ 
Konstanta 0,552 artinya jika Stres Kerja $\left(X_{1}\right)$ nilainya 0 , dan konflik kerja $\left(X_{2}\right)$ nilainya 0 , maka Kinerja Karyawan (Y) nilainya sebesar 0,552. Sedangkan koefisien regresi variabel stres kerja $\left(X_{1}\right)$ sebesar 0,495 artinya jika stres kerja mengalami kenaikan satu satuan, maka kinerja karyawan mengalami kenaikan sebesar 0,495 satuan dengan asumsi variabel independen lainnya bernilai tetap. Dan koefisien konflik kerja $\left(\mathrm{X}_{2}\right)$ sebesar 0,370 artinya jika konflik kerja mengalami kenaikan satu satuan, maka Kinerja Karyawan akan mengalami peningkatan sebesar 0,370 satuan dengan asumsi variabel independen lainnya bernilai tetap.

\section{b. Koefisien Determinasi}

Tabel 10. Hasil Uji Koefisien Determinasi

Model Summary ${ }^{b}$

\begin{tabular}{|l|l|r|r|r|}
\hline Model & $\mathrm{R}$ & R Square & $\begin{array}{c}\text { Adjusted R } \\
\text { Square }\end{array}$ & $\begin{array}{c}\text { Std. Error of } \\
\text { the Estimate }\end{array}$ \\
\hline 1 & $.757^{\mathrm{a}}$ & .573 & .543 & .29152 \\
\hline
\end{tabular}

a. Predictors: (Constant), Konflik Kerja, Stres Kerja

b. Dependent Variable: Kinerja Karyawan

Sumber : Data Primer yang Diolah SPSS Versi 22
Berdasarkan hasil pengujian koefisien determinasi pada tabel diatas, menunjukkan bahwa nilai Adjusted $R$ Square $\left(R^{2}\right)$ sebesar 0,543 . Hal ini berarti sebesar $54,3 \%$ kinerja karyawan dapat dijelaskan oleh variabel stres kerja dan konflik kerja, sedangkan sisanya sebesar $45,7 \%$ dipengaruhi oleh variabel lain diluar model.

\section{Pengujian Hipotesis}

\section{a. Uji t (Secara Parsial)}

Uji t digunakan untuk mengetahui apakah variabel independen secara parsial berpengaruh terhadap variabel dependen. Uji $t$ menggunakan SPSS Versi 22.

Tabel 11. Hasil Uji t (Uji parsial)

\begin{tabular}{|c|c|c|c|c|c|c|}
\hline \multirow[b]{2}{*}{ Mode } & & \multicolumn{2}{|c|}{ Unstandardized Coefficients } & \multirow{2}{*}{$\begin{array}{c}\begin{array}{c}\text { Standardized } \\
\text { Coefficients }\end{array} \\
\text { Beta }\end{array}$} & \multirow[b]{2}{*}{1} & \multirow[b]{2}{*}{ Sig. } \\
\hline & & $B$ & Std. Error & & & \\
\hline \multirow[t]{3}{*}{1} & (Constant) & .552 & .569 & & .969 & .341 \\
\hline & Stres Kerja & .495 & .150 & .499 & 3.310 & .003 \\
\hline & Konflik Kerja & .370 & .158 & .352 & 2.337 & .027 \\
\hline
\end{tabular}

a. Dependent Variable: Kinerja Karyawan

Sumber : Data Primer yang Diolah SPSS Versi 22

1) Variabel Stres Kerja $\left(X_{1}\right)$ Terhadap Kinerja Karyawan (Y)

Uji $t$ secara parsial untuk menguji pengaruh tiap variabel independen secara sendiri-sendiri (parsial) terhadap variabel dependen dengan membandingkan nilai $t_{\text {hitung }}$ dengan $t_{\text {tabel, }}$ jika thitung $>$ 
ttabel, maka variabel tersebut berpengaruh secara signifikan.

Dari tabel di atas untuk variabel Stres Kerja $\left(X_{1}\right)$ diperoleh thitung sebesar 3,310 dan tabel sebesar 2,048, maka dapat disimpulkan Stres Kerja $\left(\mathrm{X}_{1}\right)$ secara parsial berpengaruh signifikan terhadap Kinerja Karyawan (Y).

2) Variabel Konflik Kerja $\left(X_{2}\right)$ Terhadap Kinerja Karyawan (Y)

Untuk variable Konflik Kerja $\left(X_{2}\right)$ diperoleh $t_{\text {hitung }}$ sebesar 2,337 dan tabel sebesar 2,048, maka dapat disimpulkan Konflik Kerja $\left(\mathrm{X}_{2}\right)$ secara parsial berpengaruh signifikan terhadap kinerja karyawan $(Y)$.

b. Uji F (Secara Simultan) Menurut Priyatno (2013:122) uji $F$ digunakan untuk menguji apakah variabel independen secara simultan (bersama-sama) berpengaruh terhadap variabel dependen. Uji $F$ menggunakan SPSS 22 For Windows yaitu dengan hasil :

Tabel 12. Hasil Uji F (Uji bersama-sama)

ANOVA $^{a}$

\begin{tabular}{|ll|r|r|r|r|l|}
\hline \multicolumn{1}{|c|}{} & \multicolumn{1}{c|}{$\begin{array}{c}\text { Sum of } \\
\text { Squares }\end{array}$} & df & Mean Square & F & Sig. \\
\hline 1 & Regression & 3.199 & 2 & 1.600 & 18.822 & $.000^{\circ}$ \\
& Residual & 2.380 & 28 & .085 & & \\
& Total & 5.579 & 30 & & & \\
\hline
\end{tabular}

a. Dependent Variable: Kinerja Karyawan

b. Predictors: (Constant), Konflik Kerja, Stres Kerja

Sumber : Data Primer yang Diolah SPSS Versi 22

Uji F secara simultan (bersama-sama) adalah untuk mengetahui pengaruh seluruh variabel independen terhadap variabel dependen secara simultan (bersamasama), jika $F_{\text {hitung }}>F_{\text {tabel }}$ maka secara simultan seluruh variabel independen berpengaruh terhadap variabel dependen. Uji $\mathrm{F}$ dalam penelitian ini menunjukkan hasil sebesar 18,822 dengan demikian >

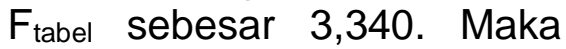
dapat disimpulkan bahwa stres kerja $\left(\mathrm{X}_{1}\right)$ dan konflik kerja $\left(X_{2}\right)$ berpengaruh positif terhadap kinerja karyawan
(Y). Metode lain juga dapat dilakukan dengan melihat angka signifikansi (sig). Jika angka sig < 0,05 maka berpengaruh, jika sig > 0,05 maka tidak berpengaruh.

Hasil

pengujian

menunjukkan angka sig 0,000 sehingga $<0,05$. Maka kesimpulannya variabel independen Stres Kerja $\left(\mathrm{X}_{1}\right)$ dan Konflik Kerja $\left(X_{2}\right)$ secara bersama-sama mempunyai pengaruh signifikan terhadap variabel dependen yaitu Kinerja Karyawan (Y) pada CV.Duta Karya (Jasa Parkir). 


\subsection{PEMBAHASAN}

Dari hasil pengujian hipotesis secara simultan menunjukkan bahwa variabel Stres Kerja $\left(X_{1}\right)$ dan Konflik Kerja $\left(X_{2}\right)$ secara bersama-sama berpengaruh signifikan terhadap Kinerja Karyawan (Y). Ini bisa dilihat dari nilai $F_{\text {hitung }}$ 18,822 dan $F_{\text {tabel }}$ untuk taraf $5 \%$ didapatkan nilai 3,340 berarti $F_{\text {hitung }}>F_{\text {tabel }}$ maka $\mathrm{H}_{0}$ ditolak dan $\mathrm{H}_{\mathrm{a}}$ diterima dan dengan probability significancy $(0,000)$ lebih kecil $0,05(\alpha=5 \%)$.

Berdasarkan hasil analisis hipotesis $X_{1}$ ternyata terdapat pengaruh signifikan antara Stres Kerja $\left(X_{1}\right)$ terhadap kinerja karyawan, ini dapat dilihat dari thitung $3,310>t_{\text {tabel }} 2,048$. Sehingga dapat dinyatakan variabel stres kerja $\left(X_{1}\right)$ mempunyai pengaruh signifikan terhadap variabel kinerja karyawan $(\mathrm{Y})$.

Berdasarkan hasil analisis hipotesis $X_{2}$ ternyata terdapat pengaruh yang signifikan antara konflik kerja $\left(\mathrm{X}_{2}\right)$ terhadap kinerja karyawan $(\mathrm{Y})$, ini dapat dilihat dari thitung 2,337 > ttabel 2,048. Sehingga dapat dinyatakan variabel konflik kerja $\left(\mathrm{X}_{2}\right)$ mempunyai pengaruh yang signifikan terhadap variabel kinerja karyawan.

Berdasarkan perhitungan Model Summary nilai adjusted $\mathrm{R}$ Square adalah sebesar 0,543 sehingga dalam penelitian ini Stres Kerja $\left(\mathrm{X}_{1}\right)$ dan Konflik Kerja $\left(X_{2}\right)$ dapat menjelaskan kinerja karyawan (Y) sampai dengan $54,3 \%$, sedangkan sisanya 45,7 $\%$ dipengaruhi oleh variabel lain yang tidak diteliti dalam penelitian ini.
Temuan penelitian ini dikemukakan oleh Soewondo dalam Suwatno dan Priansa (2013:225) yang menyatakan bahwa stres kerja adalah suatu kondisi dimana terdapat satu atau beberapa faktor di tempat kerja yang berinteraksi dengan pekerja sehingga mengganggu kondisi fisiologis dan perilaku. Stres kerja akan muncul bila terdapat kesenjangan antara kemampuan individu dengan tuntutan-tuntutan dari pekerjaannya.

Menurut Robbins dalam

bukunya Organizational Behaviour dalam Armala (2015:109) menjelaskan bahwa konflik adalah suatu proses interaksi yang terjadi akibat adanya ketidaksesuaian antara dua pendapat (sudut pandang) yang berpengaruh atas pihakpihak yang terlibat, baik pengaruh positif maupun pengaruh negatif.

Sedangkan menurut Nasucha dalam Fahmi (2013:228) kinerja adalah sebagai efektifitas organisasi secara menyeluruh untuk memenuhi kebutuhan yang ditetapkan dari setiap kelompok yang berkenaan dengan usahausaha yang sistematik dan meningkatkan kemampuan organisasi secara terus menerus untuk mencapai kebutuhannya secara efektif.

Kinerja adalah tingkat keberhasilan seseorang dalam melaksanakan pekerjaan. Sejauh mana keberhasilan seseorang dalam menyelesaikan tugas pekerjaannya disebut level of performance. Pada umumnya kinerja atau performance diberi batasan sebagai kesuksesan seseorang dalam melaksanakan 
suatu pekerjaan. Adapun baik buruknya kinerja karyawan pada suatu perusahaan bisa dipengaruhi oleh berbagai hal, diantaranya adalah stres kerja dan konflik kerja.

\section{KESIMPULAN DAN SARAN}

\subsection{Kesimpulan}

Berdasarkan hasil analisis
dan pembahasan mengenai pengaruh stres kerja dan konflik kerja terhadap kinerja karyawan pada CV.Duta Karya (Jasa Parkir) yang telah peneliti kemukakan pada bab sebelumnya, maka pada bab ini peneliti menarik kesimpulan sebagai berikut :

1. Secara parsial stres kerja berpengaruh signifikan terhadap kinerja karyawan.

2. Secara parsial konflik kerja berpengaruh signifikan terhadap kinerja karyawan.

3. Secara simultan menunjukkan bahwa variabel stres kerja $\left(X_{1}\right)$ dan konflik kerja $\left(X_{2}\right)$ secara bersamasama berpengaruh signifikan terhadap kinerja karyawan (Y).

\subsection{Saran}

Sehubungan dengan kesimpulan di atas yang telah diuraikan, maka penulis memberikan saran sebagai bahan masukan bagi CV.Duta Karya (Jasa Parkir) yang penulis ajukan berkaitan dengan penelitian, mudah-mudahan dapat diambil manfaatnya oleh perusahaan dan dapat menambah wawasan bagi mereka yang membacanya.
1. Dalam usaha peningkatan kinerja karyawan, hendaknya perusahaan lebih memperhatikan faktor-faktor yang bisa menyebabkan stres di tempat kerja dan berusaha meminimalisasi terjadinya konflik di tempat kerja. Seperti menciptakan lingkungan kerja yang nyaman, menghargai hasil kerja bawahan dan teman kerja, atasan memberikan pujian kepada karyawan yang berprestasi bagus, memberikan kewenangan yang cukup terhadap karyawan untuk melaksanakan pekerjaan, menyamakan visi antara atasan dan bawahan terhadap suatu pekerjaan dan tujuan perusahaan, menghindari terjadinya perselisihan antar sesama karyawan ataupun karyawan dengan atasan dan lain-lain. Apabila tingkat stres kerja dan konflik kerja terlalu tinggi, maka akan berpengaruh terhadap penurunan kinerja perusahaan yang ada di perusahaan tersebut.

2. Peneliti selanjutnya diharapkan lebih variatif mengembangkan faktorfaktor yang mempengaruhi kinerja karyawan, tidak sebatas pada stres kerja dan konflik kerja saja, tetapi dapat mengembangkan faktorfaktor lainnya seperti upah, tunjangan, insentif, kepemimpinan, komunikasi, dan lain sebagainya. Sebagai contoh adalah pemberian insentif yang sesuai dengan prestasi, kepemimpinan yang co-operative dan bisa 
memahami masalah yang dihadapi karyawan di tempat kerja, komunikasi yang efektif antar sesama karyawan ataupun karyawan dengan atasan dan lain sebagainya. Apabila hal-hal tersebut diatas bisa diterapkan dengan baik di perusahaan, maka akan berpengaruh terhadap peningkatan kinerja karyawan secara signifikan.

\section{DAFTAR PUSTAKA}

Armala. 2015. Meraih Sukses itu (tidak) Gampang. Jakarta: Gramedia Pustaka Utama

Diansyah, Nur Denny. 2010. Pengaruh Job Stressor (Stres Kerja) dan Konflik Kerja terhadap Kinerja Karyawan Dinas Pekerjaan Umum Pemerintah Kota Surakarta.

Fahmi, Irham. 2013. Manajemen Kepemimpinan Teori dan Aplikasi. Bandung : Alfabeta.

Nawawi, Hadari. Hadari, M. Martini. 2012. Kepemimpinan yang Efektif. Yogyakarta : Gadjah Mada University Press.

Priyatno, Dwi. 2014.SPSS 22 Pengolahan Data Terpraktis. Yogyakarta : Andi Offset.

Riva'i, Veithzal. Mulyadi, Deddy. 2010. Kepemimpinan dan Perilaku Organisasi. Jakarta : PT. Raja Grafindo Persada.

Sari, Puspita Ria. 2015. Pengaruh stres Kerja dan Konflik Kerja terhadap Kinerja Karyawan Jambuluwuk Malioboro Boutique Hotel Yogyakarta.

Siregar, Sofyan. 2013. Metode Penelitian Kuantitatif Perbandingan Perhitungan Manual dan SPSS Edisi Pertama. Kencana Prenada Media Group : Jakarta.
Sugiyono. 2012. Metode Penelitian Bisnis. Cetakan kesembilan. Bandung : CV. Alfabeta.

Sugiyono. 2015. 2015. Metode Penelitian Kuantitatif, Kualitatif, dan $R \& D$, Alfabeta, Bandung

Sujarweni, V. Wiratna. 2015. Metodologi Penelitian Bisnis dan Ekonomi. Yogyakarta : PT. Pustaka Baru.

Suwatno. Priansa, Donni Juni. 2013. Manajemen SDM dalam Organisasi Publik dan Bisnis. Bandung : Alfabeta.

Wibowo. 2012. Manajemen Kinerja. Edisi Keempat. PT. Raja Grafindo Persada : Jakarta. 